\title{
Thermal Studying Dry Chemicals as Hygienically Safe Extinguishing Substances
}

\author{
Iveta Marková*1 and Ivana Tureková \\ ${ }^{1}$ Department of Environmental Management, Slovakia \\ ${ }^{2}$ Department of Technology and Information Technologies, Slovakia
}

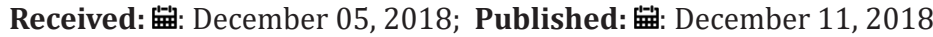

*Corresponding author: Iveta Marková, Department of Environmental Management, Faculty of Natural Sciences, Slovakia

\begin{abstract}
Dry chemicals are chemicals used in the food industry as preservatives and in agriculture as fertilizers. Due to their chemical composition, they can used as extinguishing agents. Dry chemicals are extinguishing powders, which currently belong to more principal extinguishing agents that are used for the rapid and initial firefighting. For the purposes of analysis, the samples were chosen Furex and Bavex Dry chemicals, introduced into the combustion zone, operate mostly insulatively until they are heat degradable. Their effect depends on the degree of dispersion and deposition rate. For the purposes of monitoring of the thermal lability and the subsequent disintegration of extinguishing powder was chosen the analytical method of TG, DTG - thermogravimetry, where is monitored the weight loss of samples depending on the continuous heating $\left(10^{\circ} \mathrm{C} / \mathrm{min}\right.$ in the air atmosphere). TG curves were obtained as the function of dependence of weight loss from increasing temperature. The thermal profiles presented in form of TGA curves were comparable for studied samples. All TGA curves were divided into two stages. Despite these facts, we found the certain temperature stability up to order $170^{\circ} \mathrm{C}$ for all samples of extinguishing powders.
\end{abstract}

Keywords: Dry Chemicals; Thermal Analysis

\section{Introduction}

Dry chemicals called extinguishing powders are prepared by mixing inorganicand organicsolids, ground to the prescribed particle size. These are the following dry chemicals: sodium bicarbonate $\mathrm{NaHCO}_{3}$, potassium bicarbonate $\mathrm{KHCO}_{3}$, Ammonia Bicarbonate $\mathrm{NH}_{4} \mathrm{HCO}_{3}$, diammonium hydrogen phosphate $\left(\mathrm{NH}_{4}\right)_{2} \mathrm{HPO}_{4}$, ammonium dihydrogenphosphate $\mathrm{NH}_{4} \mathrm{H}_{2} \mathrm{PO}_{4}$, diammonium sulfate $\left(\mathrm{NH}_{4}\right)_{2} \mathrm{SO}_{4}$, disodium sulphate $\mathrm{Na}_{2} \mathrm{SO}_{4}$, potassium sulfate $\mathrm{K}_{2} \mathrm{SO}_{4}$, sodium chloride $\mathrm{NaCl}$ and potassium chloride $\mathrm{KCl}$ [1-7]. Specific extinguishing powders are sodium-bicarbonate-based dry chemical [8]. Based on the conclusions of experiments, the size of powder particles was set to $0.1 \mathrm{~mm}[1-3,6]$. But Ewening et al. [9] showed that the overall effectiveness of each dry chemical depends on its particle size, the degree of its decomposition and/ or vaporization. All tested particles of chemical below a unique limiting size completely decompose and/or vaporize in the tested fire and have the same extinguishing effectiveness $[9,10]$. All powder fire extinguishing devices operate on the same principle: the powder is extruded from a vessel by the pressure of the carrier (extrusion) gas, such as argon, carbon dioxide, helium and nitrogen
$[1,3,4,7]$. Physical properties of powder fire extinguishers can be divided into (EN 615:2001) [11]: Producing properties, such as size of crystals (influenced density, filling weight and specific surface of the crystals, hydrophobic properties and Utility properties, mainly liquidity, storage, resistance against shaking, lactating with foam, electric conductivity, grinding of powder.

Thermogravimetric Analysis (TGA) is a fast method for estimating changes in materials during thermal degradation in laboratory trials $[12,13]$. In this case, the temperature of sample increases in a certain linear speed heating $\left({ }^{\circ} \mathrm{C} \cdot \mathrm{min}^{-1}\right)[14,15]$. TGA curves show the relationships between the growth and the decline of weight in depend inf of temperature. Thermal analysis allows researchers to monitor of thermal decomposition, speed of degradation and weight decline of sample. Thermal stability monitoring and subsequent thermal decomposition of extinguishing powders were investigated by the TGA, where the weight loss of the sample was monitored as a function of continuous heat loading $\left(10^{\circ} \mathrm{C} \cdot \mathrm{min}^{-1}\right)$. The resulting TG curve as a function of weight loss from the rising temperature is then derivatized. 


\section{Materials and Methods}

For the purposes of the experiment, there were used samples of fire extinguishing powders, which are currently used for filling of fire extinguishers and fire extinguishing equipment. It was a Furex pills called powder $A B C$ and powder Bavex. Brief characteristic of samples for thermal analysis enclosed in the Table 1. TGA analysis was made by the equipment METTLER TA 50 and was evaluated by authorized software.

Table 1: This is a table. Characteristics of testing material of extinguishing powder samples and experimental conditions of TG, DTG analyse.

\begin{tabular}{|c|c|c|}
\hline Extinguishing powder samples & Furex & Bavex \\
\hline Chemical components* & $\begin{array}{c}\left(\mathrm{NH}_{4}\right)_{2} \mathrm{HPO}_{4}, \mathrm{NH}_{4} \mathrm{H}_{2} \mathrm{PO}_{4}\left(\mathrm{NH}_{4}\right)_{2} \mathrm{SO}_{4}\left(\mathrm{NH}_{4}\right)_{2} \mathrm{~S}(2: 1), \mathrm{H}_{2} \mathrm{~S}, \text { Diam- } \\
\text { monium salt silica, mica, Muscovite magnesium aluminium } \\
\text { silicate }\end{array}$ & $\begin{array}{l}\mathrm{NH}_{4} \mathrm{HCO}_{3} \\
\text { A mixture of inorganic salt silicic acid, Corrosion } \\
\text { inhibitor Lubricant, Processing aid }\end{array}$ \\
\hline Mass (mg) & 8,765 & 8.088 \\
\hline Experimental Atmosphere & \multicolumn{2}{|l|}{ Air } \\
\hline Load & \multicolumn{2}{|c|}{$10^{\circ} \mathrm{C} \cdot \mathrm{min}^{-1}$} \\
\hline Airflow & \multicolumn{2}{|c|}{$0,002 \mathrm{mg} \cdot \mathrm{s}^{-1}$} \\
\hline
\end{tabular}

\section{Results and Discussion}

From the stated experimental curve, it is possible to read following quantitative appraisal of process during fluent warming the sample of extinguishing powders. $\mathrm{T}_{\mathrm{p}}$ is the temperature we could say when the process is the quickest. The value $\Delta \mathrm{m}$ presents the percent mass detect of the sample at the set interval and then Cres. presents percent residue of the sample during the thermal process. From the point of thermal analysis is the appraisal of thermal stability of the sample Furex, the oldest powder, very interesting. The beginning of the thermal dissociation of the sample happens at the temperature $163.4^{\circ} \mathrm{C}$ and then at $201.7^{\circ} \mathrm{C}$ comes to degradation the sample with the mass detect $18.39 \%$ documented in TG curve. In a given case, DTG curve would be possible to quantify several stages of degradation but there were evaluated 2 stages of thermal degradation. More interesting sounds, the reality that the initiation begins at $163^{\circ} \mathrm{C}$ and then moreover at $421.7^{\circ} \mathrm{C}$ what means the degradation in the second main stage.

The final rest is after the thermal dissociation (marked as Cres.) of original weight at temperature $510^{\circ} \mathrm{C}$ is relatively high
$30.44 \%$. Our analysis hasn't proved that the "rest" would make on the surface of burning substances melt called glaze [1]. Compared to the sample of Furex the sample of Bavex shows totally different process of thermal degradation. Initial temperature of degradation is lower (Table 2). It proves the temperature only up to $154.6^{\circ} \mathrm{C}$ that we may consider for a low thermal stability. Low thermal stability proves instant dissociation the powder on active inhibited particles. The results match with the producer statement of Safety Data Sheet of Furex which declares the thermal dissociation of Furex $149^{\circ} \mathrm{C}-288^{\circ} \mathrm{C}$. Mutual comparing of thermal parameters and that is the initial temperature of the dissociation, Tmax, that presents the temperature at which the thermal dissociation is the most intensive and the final temperature when the process of degradation is no more, and both temperatures are compared. Examined fire extinguishers are popular fire extinguishers in restaurants, grocery stores, schools and hospital premises. Their thermal stability is low and are suitable for chemical shaving systems. Their thermal stability is high for other uses in practice (household, agriculture).

Table 2: Parameters of TG a DTG analyze of experimental samples.

\begin{tabular}{|c|c|c|c|c|c|c|c|c|}
\hline Extinguishing & \multicolumn{4}{|c|}{ I. degree thermal degradation } & \multicolumn{4}{|c|}{ II. degree thermal degradation } \\
\hline & TI1 $\left({ }^{\circ} \mathrm{C}\right)$ & $\operatorname{Tp}\left({ }^{\circ} \mathrm{C}\right)$ & $\nabla \nabla^{\otimes} \Delta$ & Cres $(\%)$ & TI1 $\left({ }^{\circ} \mathrm{C}\right)$ & $\operatorname{Tp}\left({ }^{\circ} \mathrm{C}\right)$ & $\nabla \nabla^{\otimes} \mathrm{QD}$ & Cres $(\%)$ \\
\hline Furex & $163,0-325,3$ & $201,7 \pm 0.058$ & $18,39 \pm 0.081$ & $80,77 \pm 0.031$ & $325,3-510$ & $421,7 \pm 0.049$ & $50,33 \pm 0.080$ & $30,44 \pm 0.062$ \\
\hline Bavex & $154,6-334,1$ & $211,7 \pm 0.158$ & $21,73 \pm 0.029$ & $77,12 \pm 0.021$ & $334,1-510$ & $445,0 \pm 0.099$ & $31,66 \pm 0.027$ & $45,46 \pm 0.019$ \\
\hline
\end{tabular}

\section{References}

1. Gaviglio A Bertocchi M Demartini EA (2017) A tool for the sustainability assessment of farms: Selection adaptation and use of indicators for an Italian case study. Resources 6(4): 60.

2. Kalousek J (1999) Basic of physical-chemical fire, explosion and extinguishing, ( $1^{\text {st }}$ edn). Czech Republic pp. 186-188.

3. Balog K (2005) Safe handling of extinguishing agents: Environmental and technical requirements for replacement of extinguishing substances in the Slovak Republic, ( $1^{\text {st }}$ edn). Slovak Technical University pp. 150.
4. Marková I (2008) Extinguishing agents - possibilities and ways of testing them. p. $45-110$

5. Ewing TC, Faith FR, Hughes JT, Carhart HW (1989) Flame extinguishment properties of dry chemicals: Extinction concentrations for small diffusion pan fires. Fire Technology 25(2): 134-149.

6. Schroll RC (2002) Industrial fire protection handbook. In: Portable fire extinguishers, (2 ${ }^{\text {nd }}$ edn). CRC Press pp. 145-170.

7. Orlíková K Štroch P (2002) Extinguishing agents - classic and modern, ( $1^{\text {st }}$ edn). SPBI Ostrava Czech Republic p. 72-84. 
8. Hodges S, McCormick S (2013) Fire extinguishing agents for protection of occupied spaces in military ground vehicles. Fire Technology 49(2): 379-394.

9. Curtis T Ewing, Francis R Faith, James B Romans, Charles W Siegmann, Ralph J Ouellette, et al. (1995) Extinguishing class A fires with multipurpose chemicals. Fire Technology 31(3): 195-211.

10. Curtis T Ewing, Francis R Faith, James B Romans, Charles W Siegmann, Ralph J Ouellette, et al. (1995) Extinguishing class B fires with dry chemicals: Scaling studies. Fire Technology 31(1): 17-43.

11. STN EN 615 (2001) Fire protection. Extinguishing agents. Powder requirements (excluding Class D powders).

ISSN: 2574-1241

DOI: 10.26717/BJSTR.2018.11.002175

Iveta Marková. Biomed J Sci \& Tech Res

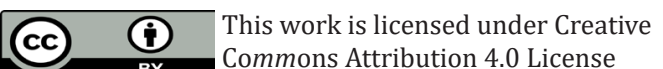

Submission Link: https://biomedres.us/submit-manuscript.php
12. Saito N, Ogawa Y, Saso Y, Liao C, Sakei R (1996) Flame-extinguishing concentrations and peak concentrations of $\mathrm{N}_{2}, \mathrm{Ar}_{2} \mathrm{CO}_{2}$ and their mixtures for hydrocarbon fuels. Fire Safety J 27(3): 185-200.

13. Brown ME, Gallagher PK (2008) Handbook of thermal analysis and calorimetry, (2 ${ }^{\text {nd }}$ edn). Elsevier 5(1): 755.

14. Materazzi S, Vecchio S, De Angelis CS (2013) Thermal analysis and health safety. J Thermal Anal Calori 112(1): 529-533.

15. Lyon ER, Walters RN, Stoliarov SI (2007) Thermal analysis of flammability. J Thermal Anal Calori 89(2): 441-448.

$\begin{array}{ll}\text { BIOMEDICAL } & \text { Assets of Publishing with us } \\ \text { RESEARCHES } & \text { - Global archiving of articles } \\ \text { - Immediate, unrestricted online access }\end{array}$

